\title{
Respiratuar distress due to giant innominate artery aneurysm
}

\section{Dev innominate arter anevrizmasına bağll solunum yetmezliği
Şevki Hakan Eren, Illhan Korkmaz*, Fatma Mutlu Kukul Güven, Ahmet Türkdoğan, İnan Beydilli, Birdal Yıldırım

Department of Emergency Medicine (Assist. Prof. Ş. H. Eren, MD, Assist. Prof. İ. Korkmaz, MD, Assist. Prof. F. M. K. Güven, MD, A. Türkdoğan, MD), Cumhuriyet University School of Medicine, TR-58140 Sivas, Emergency Department (İ. Beydilli, MD), Kayseri Teaching and Research Hospital, TR-38010 Kayseri, Emergency Department (B. Yıldırım, MD), Muğla State Hospital, TR-48000 Muğla

\begin{abstract}
Innominate artery aneurysms are rare and described in relation to atherosclerosis or syphilis and, to a lesser extent, to Takayasu disease, trauma, chronic dissection, bacterial infection, and collagen disorders. Chest pain, hoarseness, dyspnea, and dysphagia are among the complaints. Some of them are asymptomatic and are revealed by a chest X-ray incidentally. We presented a giant innominate artery aneurysm with trombosis which compressed the trachea and two main bronchus. A multidisciplinary approach as medical, surgical, and interventional pulmonology options should be considered for the patients with serious tracheal compression.
\end{abstract}

Keywords: Tracheal compression, respiratuar distress, innominate artery aneurysm

Özet

İnnominate arter anevrizmaları nadir görülmekte olup sıklıkla ateroskleroz ve sifilize bağlı olarak ortaya çıkmakta, daha az oranda Takayasu hastalığı, kronik disseksiyonlar, bakteriyal enfeksiyonlar ve kollajen doku hastalıkları ile beraber görülebilir. Göğüs ağrısı, horlama, nefes darlığı ve yutkunma zorluğu hastanın şikayetleri arasında yer alır. Bazıları asemptomatik seyreder ve çekilen akciğer grafileri sonucunda tesadüfen tespit edilir. Biz tromboze olmuş dev bir innominate arter anevrizmasına bağlı olarak trakea ve iki ana bronşta basıya neden olan bir olguyu sunduk. Ciddi şekilde trakeada basıya neden olan hastaların tedavisinde medikal, cerrahi ve girişimsel işlemlerin hepsinin yer aldığı multidisipliner bir yaklaşım tercih edilmelidir.

Anahtar sözcükler: Trakeal kompresyon, solunum yetmezliği, innominate arter anevrizması

Geliş tarihi/Received: October 04, 2011; Kabul tarihi/Accepted: April 04, 2012

\section{*Corresponding author:}

Dr. İlhan Korkmaz, Acil Tip Anabilim Dalı, Cumhuriyet Üniversitesi Tıp Fakültesi, TR-58140

Sivas. E-mail: ilhankorkmaz100@hotmail.com

\section{Case report}

A 78 year old woman was admitted to our emergency department due to cough, hemoptysis, fever and respiratuar disstres, which has increased since 2 days. She had hypertension and dyspnea in her medical history. Arterial BP was 110/70 $\mathrm{mmHg}$; respiratory rate, 24/min; pulse rate, 116 beats $/ \mathrm{min}$; and axillary temperature, $36.9^{\circ} \mathrm{C}$. In her physical exam wheezing and central cyanosis has been revealed and bronchodilatator treatment was prescribed by the emergency physycian. 


\section{Laboratory findings:}

Laboratory findings included the following: arterial blood gas tests showed $\mathrm{pH}=7.34$, $\mathrm{pO}_{2} 50 \mathrm{mmHg}, \mathrm{pCO}_{2} 55 \mathrm{mmHg}, \mathrm{HCO}_{3} 22 \mathrm{mEq} / \mathrm{L}$, and oxygen saturation, $84 \%$. She had leukocytosis, mildly increased blood urea nitrogen $(38 \mathrm{mg} / \mathrm{dL})$, creatinine $(2.2 \mathrm{mg} / \mathrm{dL})$ and blood glucose $(289 \mathrm{mg} / \mathrm{dL})$. A chest $\mathrm{x}$-ray showed a giant round density between right upper lung lob and compressed trachea (Figure 1).

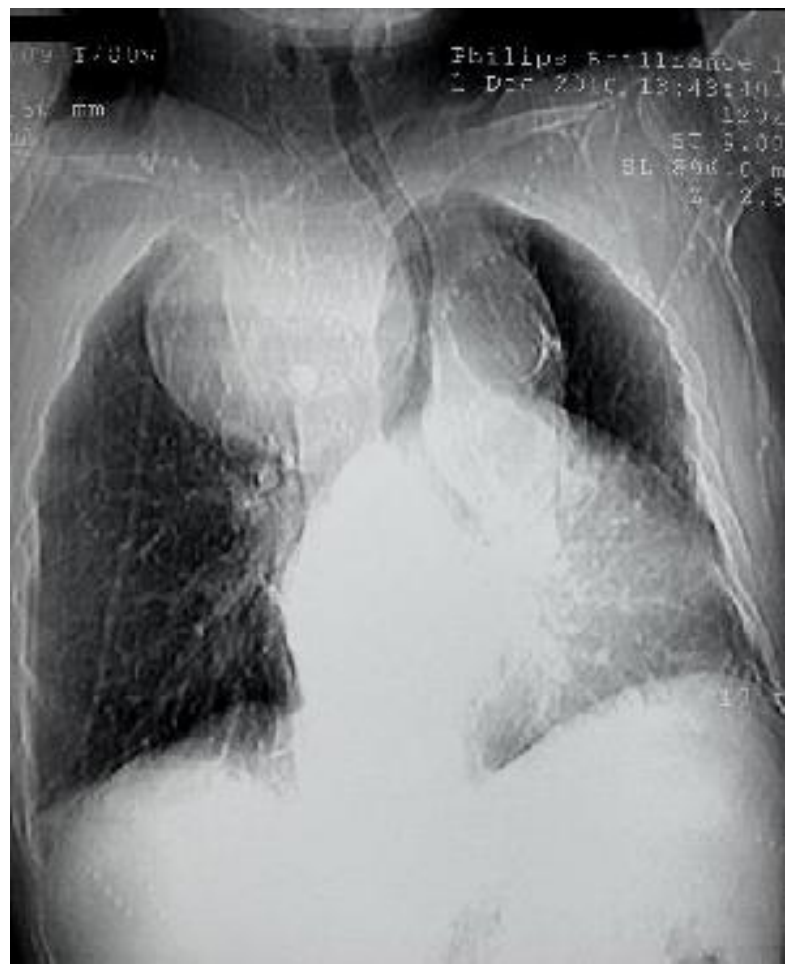

Figure 1. Giant round density in the right upper lung lob.

Contrast Computed tomography of the chest revealed a brachiocephalic artery aneurysm which reached to $8.5 \mathrm{~cm}$ in its widest part. Chronic thrombosis in the lumen was seen reaching a thickness of $5 \mathrm{~cm}$ with calcifications. Brachiocephalic artery aneurysm compressed also trachea, right and left main bronchus, esophagus and adjacent venous structures. There was also a circular thrombosis surrounding ascendan ve descendan aorta with calcifications (Figure 2a-b).

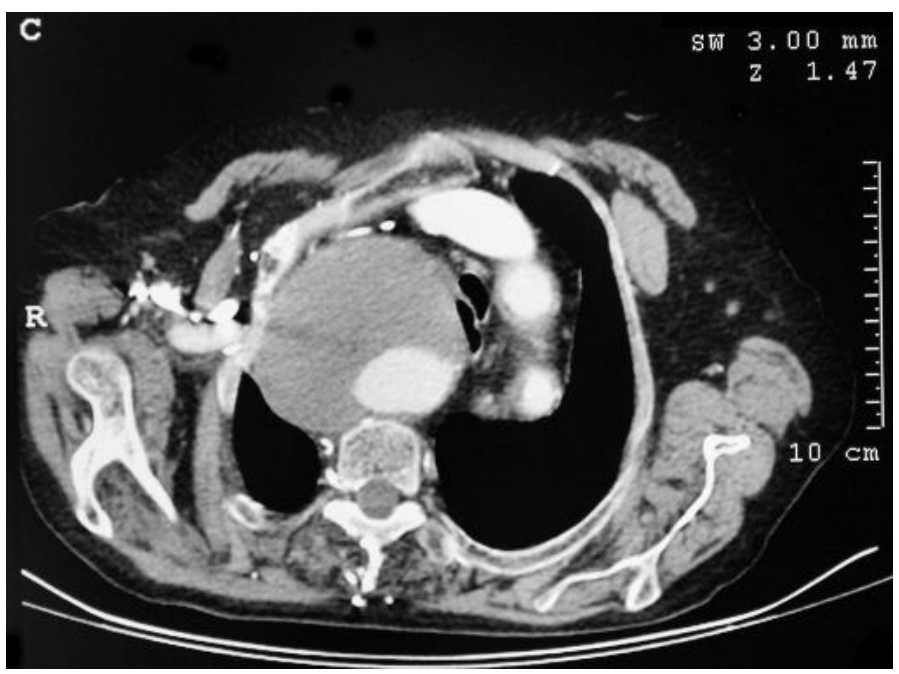

Figure 2a. An aneurismatic ascending aort with thrombosis. 


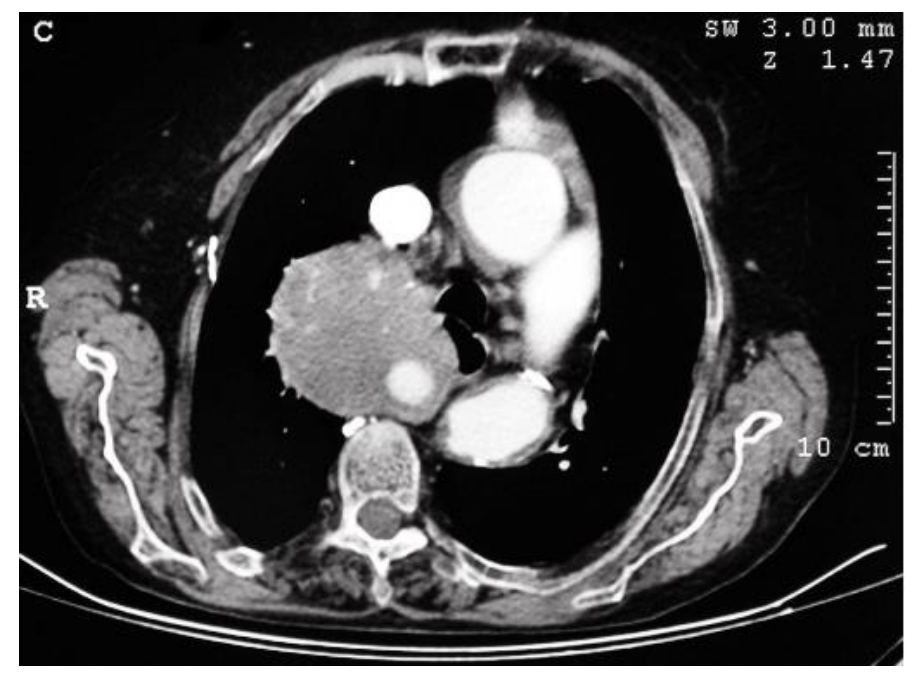

Figure 2b. Thrombosis and calcifications in ascending and descending aorta.

Surgical treatment was offered to the patient but she rejected. While the respiratory distress continued the patient was treated symptomatically in the emergency ward with supplemental oxygen, bronchodilators and intravenous hydration. This treatment was unsuccesful and respiratory arrest occured within a few hours. The patient was entubated and referred to intensive care unit. Surgical treatment was not accepted by her family while she was in the intensive care unite also, in the 10th day cardiac arrest ocurred and the patient died.

\section{Discussion}

Innominate artery aneurysms are rare and only $3 \%$ of the total number of cases of aneurysms correspond to aneurysms of the innominate artery. Atherosclerosis, syphilis, Takayasu disease, trauma, chronic dissection, bacterial infection, and collagen disorders are other possible causes [1]. Patient may complain of chest pain, hoarseness, dyspnea, and dysphagia. Physical examination may reveal supraclavicular pulsatile mass and prominent neck veins. Other manifestations may occur due to embolism or thrombosis, causing cerebral ischemia, ocular deficits, or vertebrobasilar syndrome. In some cases, innominate artery aneurysm is asymptomatic or neglected by the patients and may be detected in the chest X-ray as a mass in the superior mediastinum with tracheal deviation to the left [1-3]. Primary lesions of mediastinal origin, pleural masses, bronchial and esophageal carcinomas and vascular aneurysms take place among the differential diagnosis of the patients with a right paratracheal mass and respiratory distress [4]. Tracheal compression due to brachiocephalic artery aneurysms have been reported in the medical literature. When the compression in the tracheal tract becomes severe, patients develop respiratory distress $[5,6]$. Surgical treatment is always the first choice among the symptomatic patients and surgical procedures differs according to the type and extent of the lesion. A multidisciplinary approach as medical, surgical, and interventional pulmonology options should be considered for the patients with serious tracheal compression .In case of persistent dyspnea, stenting of the trachea can be considered [1, 2].

Although brachiocephalic artery aneurysms in adulthood are rare they should be kept in mind for the respiratuar distress differential diagnosis, and a multidisciplinary approach should be performed. 


\section{References}

1. De Feiter PW, van Mook WN, Jacobs MJ. Tracheal compression caused by an innominate artery aneurysm after thoracic aortic aneurysm repair in a patient with Marfan disease. J Thorac Cardiovasc Surg 2005; 129: 943-4.

2. Takaba K, Aota M, Koike H, Konishi Y. Surgical treatment for intrathoracic aneurysm of the innominate artery in an 83-year-old asymptomatic woman. Jpn J Thorac Cardiovasc Surg 2004; 52: 194-7.

3. Villegas-Cabello O, Cooley DA. Aneurysm of the innominate artery with aberrant origin of the left carotid artery. Case report. Tex Heart Inst J 1996; 23: 298-300.

4. Reddi AA, Munasur MM, Naidoo RR, Steer DD. Traumatic innominate artery aneurysm 26 years after stab injury. Ann Thorac Surg 2005; 79: 1034-6.

5. Sato E, Koyama S, Kamijyo H, Kobayashi O, Terashima M, Kubo K. Respiratory distress due to tracheal compression by the dilated innominate artery. Eur Respir J 1999; 14: 723-4.

6. Grossman C, Shepherd RW. Complex Management of Tracheal Obstruction Due to a Brachiocephalic Artery Aneurysm. J Bronchol 2007; 14: 108-10. 